* Corresponding author Phone: +421556022158 E-mail address:kamil.madac@tuke.sk (Kamil Madáč, doc. Ing. CSc.)

Article information Article history: Volume15-No.4-00132-11 Received 28 March 2011 Accepted 24 May 2011

\section{Informatics Support of the CENTRE OF EXCELLENCE}

\author{
Kamil Madáč , Ján Král’ml. \\ Computer Center and the editorial, Faculty of Mechanical Engineering, Mäsiarska 74, 04201 Košice, Slovak Republic
}

\section{BIOGRAPHICAL NOTES}

Kamil Madáč, Associate professor, PhD. Born in 1949. He studied at the Faculty of Mechanical Engineering of Technical University (former VST) of Košice. In 1985he defended hisdoctoral dissertationat the Faculty of Mechanical Engineering of Slovak Technical University of Bratislava, in the field of study Production systems. In 1995he defended his habilitation thesis at Technical University in Košice. He has participated in solutions of a number of scientific and research projects as principal investigator. Ján Král', Assistant professor, PhD. Born in 1976. He studied at the Faculty of Mechanical Engineering of Technical University of Košice. In 2009 he defended dissertation at the Faculty of Mechanical Engineering of TU of Košice, in the field of study Engineering Technologies and Materials. He has participated in solutions of a number of scientific and research projects

Activity 1.4: Specification requirements and ensure the implementation of the supporting information infrastructure of the Centre of Excellence.

Objective: Create an organizational and management structure and geographic information infrastructure and to ensure the effective mission of the Centre of Excellence.

\section{KEY WORDS}

Linux, Monitoring, Data Management, Open Source.

\section{ABSTRACT}

Modern engineering technology in the Centre of Excellence need the best support communication and computing infrastructure. It is not just about hardware devices but also software and training staff. The big advantage is maximum use of the socalled "open source" system, where operating costs are minimal and often have much more support than closed commercial systems.

\section{Introduction}

Editorial and Computer Center (PaEC) solves activity number 1.4 Software and hardware resources to implement the communication, presentation and archiving the results of other project activities of the Centre of Excellence (Centex). To implement the servers, x64 architecture was chosen, which would have the power and technology sufficient to cover the requirements of other activities.

Networks of individual activities is provided by the network's original TUKE and metallic own gigabit network, which provides intensive data transfer from camera systems. They monitor and record the processes designed for the project. To maximize the use of new information resources and infrastructure it is necessary to ensure the use of corresponding professional level project leaders. It will provide effective courses that will be implemented through the Web module. 


\section{Hardware equipment}

Basic equipment for portal server is a modern dual-core server (Fig. 1) with six terabytes of hard disk space and 16 gigabytes of memory. Data are provided for RAID5 disk array, which does not matter any disk failure in the server, without compromising data loss. Selected hardware should be sufficient to cover performance-capacity requirements across the Faculty of Mechanical Engineering. Server, along with other servers located in the so-called air-conditioned room of our department - inside "rack". Managing and administration of all servers is performed through a KVM switch with an LCD monitor (Fig. 2). All servers are backed up by UPS devices from APC, in case of power failure. Power is available on servers running smoothly for at least 30 minutes.

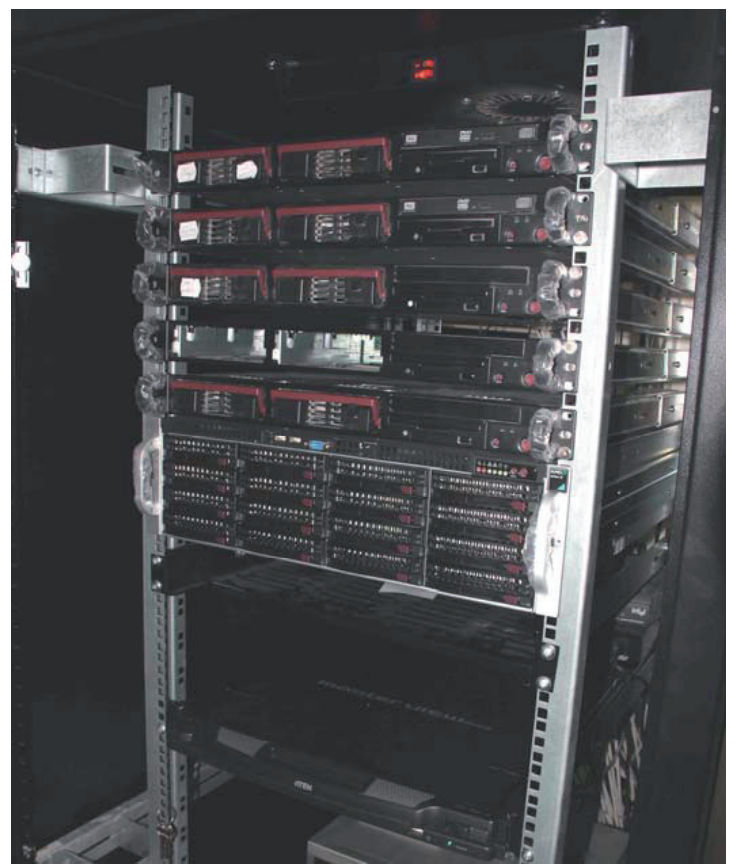

Fig. 1: Servers in the "rack".

For the purpose of presenting the results of the project is available portal server equipped with a single processor, expandable to two. The capacity of disk space is two-terabytes and main memory is the eight gigabyte. On the server there are two two-terabyte drives in RAID1 array, which does not matter any disk failure of one of them without any data loss, or threat to system functionality. minutes The last server in the activity is the monitoring server. His role will be to collect data from the IP cameras that are located on other places of the Centre of Excellence. Since it is assumed that the server will perform the most demanding tasks, contains two processors, expandable to four, has a memory capacity of 16 gigabytes and disk capacity of 20 terabytes. Array in the server version is based on RAID6. This version can withstand failure of any two drives in the system without loss of function of the server.

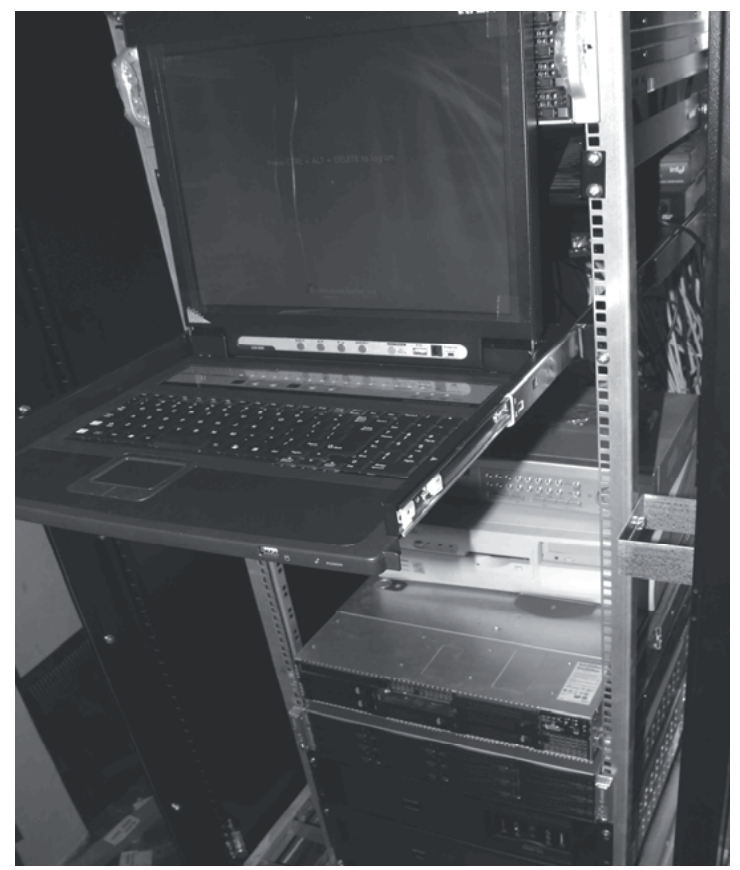

Fig. 2: KVM switch with an LCD monitor

Given sufficient experience with the reconstruction of data from arrays, all arrays are software even though at the cost of reducing performance. The closed field of hardware array in case of crash did not bring so many tools to reconstruct the data as is the case of the software field.

Infrastructure network between servers and workstations is secured by structured wires CAT5 or CAT6 controlled by manageable gigabit switch.

\section{Server and its software}

Server operating system was chosen for easier maintenance of the same in Linux, namely Debian distribution. It is a modern 64-bit operating system suitable for server use. Debian is a free (free software) operating system (OS) for computers. The operating system consists of basic programs and utilities that let you work with your computer. 
Debian uses the Linux kernel (the core of an operating system), but most of the basic OS tools come from the GNU project, hence the name GNU / Linux.

Web services running on the client - server (Fig. 1) is used by Apache 2 web server with support for PHP scripting language and MySQL database and PostreSQL.

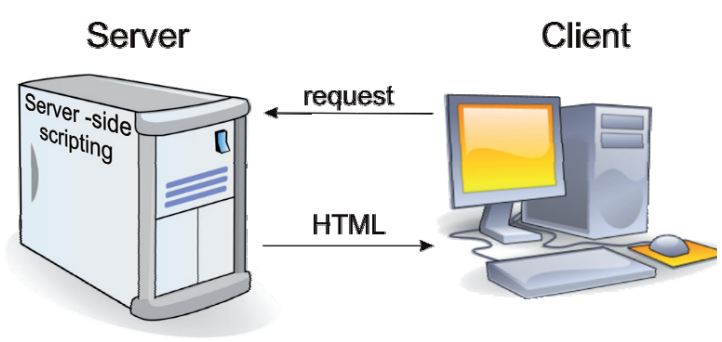

Fig. 3: Description relation client - server.

On the site ww.sjf.tuke.sk / CE there is portal of Center of Excellence, which serves to communicate the status of activities and their solutions. The system has a public and private part. The internal part is only accessible to project solvers.

On the portal server is available system to train researchers Centex for training in new technologies. For the training of investigators, we selected and expanded internationally used system Moodle. This is a software package for producing internet-based courses and web sites. It is a system that is constantly being added and developed. The system is provided freely as Open Source software (under GNU Public License).

In essence, this means that it is copyrighted, but still provides a certain freedom. For example, it allows you to copy, use and modify under the condition that the modified code will be provided to users, while it will not modify or remove the original license and copyrights, and using the same license to any derivative work. If there are any questions or concerns it is best to directly contact the copyright holder.

Moodle works on any computer on which PHP is installed and supports multiple types of databases (especially MySQL). The word Moodle was originally an acronym for Modular Object Oriented Dynamic Learning Environment (Modular Object Oriented Dynamic Learning Environment), this information may be mostly useful to programmers.
For the solution of the portal system was purchased PDF documents PDFlib to create commercial application that can integrate into their web applications. This allows fast and efficient way to convert data from various sources into PDF format, which is now standard in the world for exchange of documents.

\section{Software for desktops}

For the processing of documents for e-learning teaching has been purchased a comprehensive package from Adobe Master Collection in the 5. version.

By means of the package we can create and edit PDF files, edit video files in different formats, edit bitmap and vector graphics, create static and dynamic web pages, edit audio tracks, flash, animation, etc.

The limitation of this package of programs is in the number of available licenses. At our workplace we have now purchased one license software package Adobe Master Collection, which is not floating but static. can only be used on one computer. If interested, you can try free 30 day trial, which is not limited in any way. You can download it from Adobe company inc. www.adobe.com. Slovak localization is only partial, for full use is recommended to use the English version.

\section{Conclusion}

Modern mechanical engineering technology require the support of modern information and communication technologies. Their base is built up infrastructure and hardware. At our workplace, "Computer and Publishing Centre" we have hardware and software equipment that is currently being tested for full commitment to service. Live operation is planned for 2012. It will also include training investigators for the effective use of ICT resources.

\section{Acknowledge}

The paper has been prepared on the basis of project: Management research center technical, environmental and human risks to continuous development and production of products in engineering 26220120060 - by supporting operational research and development program funded by the European Regional Development Fund. 


\section{References}

[1] Spišák E., Badida M., Kmec J., Sobotova L.: Identification of Structure of Hydro-Erosion Operation / Emil Spišák ... [et al.] - 2011. In: Acta Mechanica Slovaca. Roč. 15, č. 2 (2011), s. 8086. - ISSN 1335-2393

[2] Kamil Madač: Development of Information Technology Faculty of Mechanical Engineering at TU / - 2005. In: Stan, problemi ta perspektivi integraciji Ukrajini u evropejskij osvitnij i naukovij prostir. - Užhorod : ZDU, 2005 P. 57-60. - ISBN 9668110196

[3] The influence of shape for self-reconfigured modular robotic system characteristics / František Trebuňa, Juraj Smrček, Zdenko Bobovský - 2010. In: Acta Mechanica Slovaca. Roč. 14, č. 1 (2010), s. 6-12. - ISSN 1335-2393 [TREBUŇA, František
- SMRČEK, Juraj - BOBOVSKÝ, Zdenko]

[4] Kamil Madáč, Michal Varchola: It and training of cad design / 2007. In: Sučasni informacijni technologii ta innovacijni metodiki navčannja fachivciv na mižnarodnomu rinku viščoi osviti. - Užgorod : Lira, 2007 P. 116-125. - ISBN 9789668266751

[5] Ján Král', Ján Král' ml.: Contribution to teaching of selected subject in the uLern system - 2004. In: Acta Mechanica Slovaca. Roč. 8, č. 2-B PRO-TECH-MA (2004), s. 247-250. - ISSN 1335-2393

[6] http://www.debian.org/, 2.10.2011

[7] http://www.moodle.sk/mod/resource/view.php?id=2, 2.11.2011

[8] http://www.adobe.com/products/creativesuite/mastercollection.html, 2.10.2011

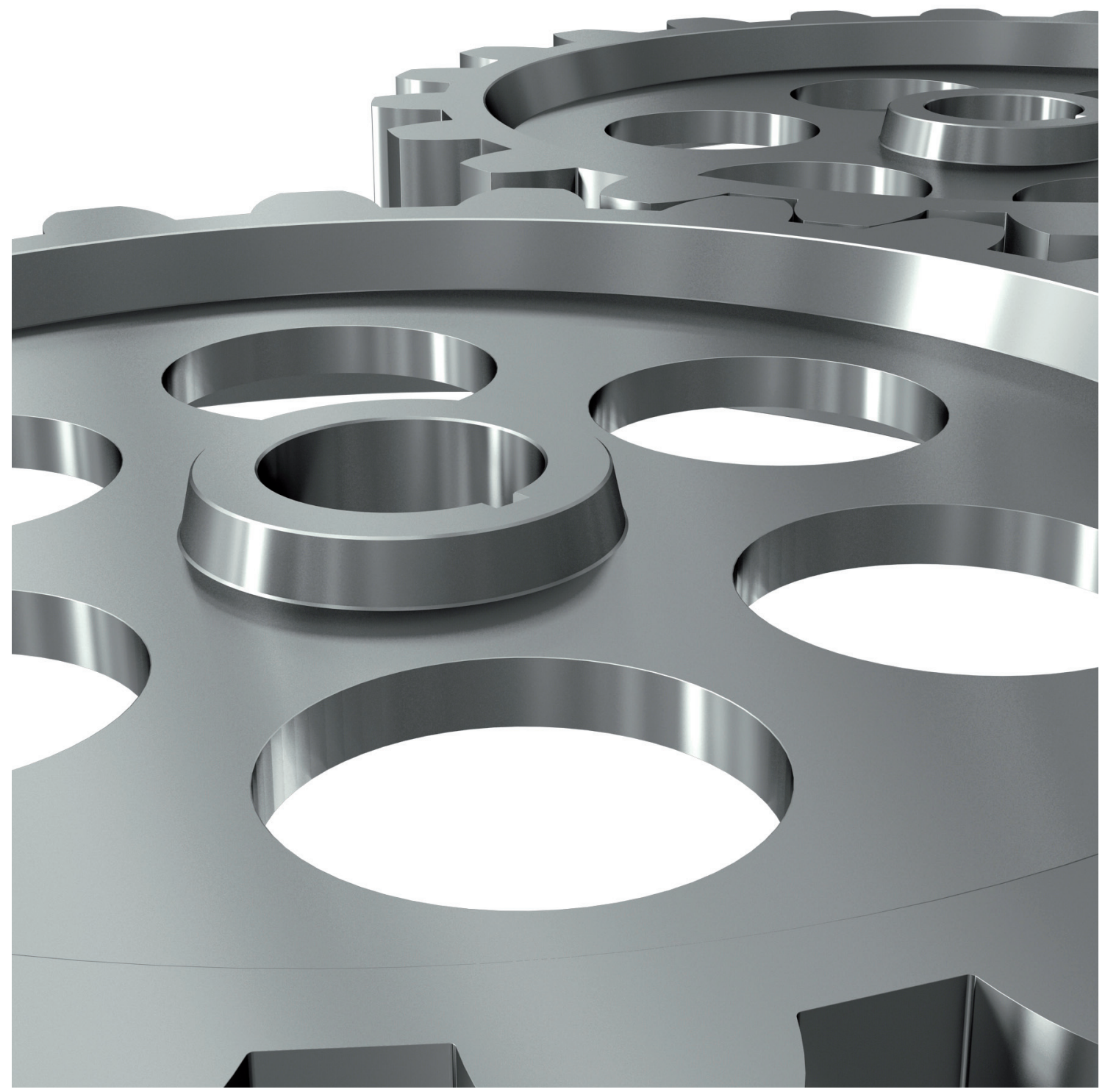

